\title{
O REI DO OBÓ: MEMÓRIA E MITO NA DRAMATURGIA SÃO-TOMENSE DE FERNANDO DE MACEDO
}

\author{
Luciana Éboli \\ (Centro Universitário La Salle - Unilasalle/RS)
}

\begin{abstract}
RESUMO
O presente trabalho analisa um texto representativo da dramaturgia africana de língua portuguesa da atualidade: O rei do obó (1999), do dramaturgo Fernando de Macedo, de São Tomé e Príncipe. As memórias que embasam as narrativas fundadoras transformam-se, muitas vezes, em contos, lendas, fábulas e mitos, cujos enredos imaginários rememoram fatos históricos do arquipélago e tratam dos valores tradicionais dos povos de diferentes origens que lá vivem. Esses enredos surgem com base em personagens importantes na formação das comunidades e vêm reafirmar a memória coletiva, cujo valioso patrimônio cultural formado pelas particularidades regionais e pelas diversidades sociais, observado no âmbito da literatura de tradição oral, interliga as referências socioculturais e histórico-geográficas.
\end{abstract}

PALAVRAS-CHAVE: literatura Africana, memória, São Tomé e Príncipe.

\begin{abstract}
This study intends to analyze a representative text from African Portuguese-written today's dramaturgy: O rei do obó (1999), by the playwright Fernando Macedo, from São Tomé and Príncipe. The memories that underlie the founding narratives become often in tales, legends, fables and myths, whose stories recount historical facts of the archipelago and discuss traditional values of people from different backgrounds who live there. These stories reaffirm the collective memory, whose cultural heritage formed by regional particularities and the social diversity observed in literature from oral tradition, interconnects references sociocultural, historical and geographical.
\end{abstract}

KEYWORDS: african literature, memory, São Tomé and Príncipe. 


\section{INTRODUÇÃO}

Ao estudar as narrativas míticas nas culturas africanas, é de suma importância lembrar que essas se originaram e se mantiveram através das narrativas de tradição oral dos povos e suas linguagens. Fernando Vale (2001) destaca, nos países de lígua portuguesa, o valioso patrimônio cultural formado pelas particularidades regionais e pelas diversidades sociais que, observado no âmbito da literatura de tradição oral, interligam as referências socioculturais e histórico-geográficas. Essas narrativas buscam no passado os eventos formadores das diferentes identidades para, na reatualização dos enredos, identificar as forças intrínsecas da terra e do povo.

O mito nas culturas africanas faz parte de uma estrutura de conhecimento individual e coletiva, participa da memória da comunidade e também da tradição ancestral (Ndaw, 1983). Dessa maneira, ao retomar o passado, o mito torna-se um meio eficaz de manter a memória coletiva: faz parte da tradição oral e funciona como elemento de coesão social. As ligações entre a cosmologia e as diversas áreas da vida social são estreitas e representadas nas mais variadas atividades: seja no trabalho, nas formas de cultivo ou nas diferentes manifestações artísticas. Portanto, o homem e o cosmos, no pensamento mítico, se refletem reciprocamente, atraves de imagens simbólicas que se reorganizam na formação da sociedade, seja na casa ou na própria comunidade.

Em São Tomé e Príncipe, as memórias que embasam suas narrativas fundadoras transformam-se, muitas vezes, em contos, lendas, fábulas e mitos, cujos enredos imaginários rememoram fatos históricos do arquipélago e tratam dos valores tradicionais dos povos de diferentes origens que lá vivem. Muitas vezes, esses enredos surgem com base em personagens importantes na formação das comunidades e vêm reafirmar a memória coletiva, além de apresentarem a força que tais figuras exercem no imaginário popular. No caso do povo de origem angolar, que compõe parte da população são-tomense, percebe-se uma ligação intrínseca dessas memórias com os fatos, conflitos e personalidades ligados à própria identidade cultural. A dramaturgia de Fernando de Macedo, de ascendência são-tomense-angolar, retoma, através do texto O Rei do Obó, essas memórias, e trata-as a partir da perspectiva de formação mítica de uma personalidade histórica de suma importância para a formação e transformação da população das ilhas.

\section{REI AMADOR, OS CONFLITOS DA POVOAÇÃO E AS MEMÓRIAS DA ORIGEM ANGOLAR}

Em termos geográficos, o espaço de São Tomé e Príncipe forma um arquipélago, com ilhas de formação vulcânica e vegetação abundante, ocupado pelos portugueses entre 1460 e 1470. À época, um núcleo urbano denominado Povoação se estabeleceu ao nordeste da ilha de São Tomé, cuja população formou-se, em sua maioria, por europeus e escravos oriun- 
dos de localidades da costa da África. A economia da ilha inicia-se após a fixação dos colonos e gira em torno da economia açucareira, o que demanda um grande numero de escravos. A dificuldade de adaptação à alimentação local pelos europeus cria a necessidade de importação de produtos realizada através de "amplo ancoradouro para os navios que traziam farinha, vinho, azeite, queijos e outros produtos" (MACEDO, 19996, p. 26), e de onde saíam os navios com grandes carregamentos de açúcar para o mercado de Flandres.

No período de 1470 a 1485, a economia principal da ilha girou em torno da produção de cana-de-açúcar. Posteriormente, foram inseridas as produções de cacau e fumo, o comércio de pimenta e madeira e o sistema de latifúndio e monocultura, cujas propriedades recebem o nome de "roças". Durante o período colonial, a necessidade de grande quantidade de mão de obra escrava para manutenção da economia aumentou o tráfico de escravos, o que acarretou o aumento considerável do número de habitantes da ilha: o mar torna-se, nesse contexto, fundamental meio de trânsito e abastecimento de escravos aos engenhos das ilhas. Além disso, ao comércio negreiro acrescenta-se a finalidade de 'armazenagem' de escravos enquanto aguardavam transporte para outros destinos. Assim, os cativos eram mantidos em fazendas até ao dia do embarque, e o tempo que decorria entre a chegada do continente e a partida para os demais portos importadores correspondia à estadia de grandes quantidades de escravos no espaço insular. Conforme Tenreiro (1961), a situação privilegiada da ilha de São Tomé, no Atlântico e à beira do hemisfério sul, exerceu grande atração sobre os portugueses e tornou-se ponto de encruzilhada de transportes culturais provenientes de Portugal e da costa africana e, posteriormente, da Índia e do Brasil.

A invasão territorial e o processo de colonização, porém, transformaram a realidade da ilha e trouxeram, no decorrer do tempo, suas conseqüências: as más condições de trabalho, o tratamento hostil e o excesso de pessoal foram motivos fundamentais para que ocorressem as revoltas de escravos contra colonos. Na maior parte das vezes, as revoltas foram reprimidas pelos donos dos engenhos que possuíam mais possibilidades de defesa, incluindo armas de fogo. Ainda assim, uma grande quantidade de escravos conseguiu escapar e se refugiar no interior da ilha, onde se reuniram em grupos que continuaram a atacar os engenhos, com incêndios e mortes. Os ataques freqüentes causaram o enfraquecimento das grandes propriedades e a crise dos senhores de engenho, que originaria a chamada "Guerra do Mato", caracterizada pela incursão na floresta pelos colonizadores, os capitães-do-mato, com o objetivo de capturar os fugitivos. Essas expedições eram organizadas pelos governadores e fazendeiros depois de pedirem auxílio militar a Lisboa. A situação, porém, apresentava-se crítica, com o esvaziamento das fazendas e a crise em Portugal ocasionada pela morte de D. Sebastião na batalha de Alcácer-Quibir, em 1578.

Para Pereira (2009), a "Guerra do Mato" efetivou-se a partir do século XVII, quando realmente houve a ofensiva sobre os colonizados, e 
teve desdobramentos nos séculos seguintes até a ocupação de Santa Cruz dos Angolares pelos portugueses, em 1878, com oposição liderada por Simão Andreza - o último rei angolar que, por sua vez, dera continuidade à figura mítica do Rei Amador, escravo fugitivo e autoproclamado rei de São Tomé em julho de 1595 -. O Rei Amador realizou a mais conhecida revolta de escravos de São Tomé: por ter sido escravo de um capitão-do-mato, aprendeu estratégias de guerra e organizou de forma militar um enorme contingente para combater os colonos, libertou grande parte do território, bem como dominou a administração colonial localizada na capital. Devido ao menor poderio bélico e à traição de alguns membros do grupo, Amador foi capturado e assassinado em janeiro de 1596, mas, ainda assim, permanece na memória são-tomense como o primeiro rei dos angolares.

Os angolares habitaram a zona sul de São Tomé em condições de grande isolamento devido à inacessibilidade do terreno e à densa floresta que cobria grande parte da ilha. Desenvolveram identidade sócio-cultural própria e uma economia de subsistência, sendo que essa forma de exclusão tornou-se, assim, um meio de sobrevivência. Depois de terem suas terras espoliadas no século XIX, voltam-se ao mar e à atividade pesqueira, sobre a qual registra Almada Negreiros, em 1893, na obra História ethnographica da ilha de S. Tomé - o autor identifica os angolares como intrépidos marinheiros, construtores de canoas e produtores de fios e materiais para pesca: "tudo fabricam com admirável perfeição, utilizando-o em serviço próprio e vendendo-o nas feiras e nas praias" (NEGREIROS, 1893, p. 298). Nos estudos sobre a origem do povo angolar, há três hipóteses levantadas por Fernando de Macedo (1996): a hipótese do naufrágio de um navio angolano, da prioridade africana e da descendência de escravos de outras regiões da África.

A primeira hipótese é a de que os angolares descendem de escravos fugitivos de um navio negreiro, originário de Angola, que naufragou perto da ilha por volta do ano de 1540, nos rochedos de Sete Pedras ${ }^{1}$. Esses fugitivos angolanos teriam construído aldeia no interior da floresta, onde se mantiveram em isolamento e, cerca de três décadas depois, deixaram o mato para saquear os engenhos.

A segunda hipótese, da "prioridade africana", questiona o fato de a ilha de São Tomé ser desabitada quando da sua descoberta, e defende que a presença dos angolares é anterior à chegada dos portugueses. Desde a década de 1970, pesquisadores propõem que os angolares seriam uma ramificação dos bantu que se teria fixado nas regiões do Gabo e do rio Muni, e posteriormente migrado para as ilhas do Golfo. Posteriormente teriam sido dizimados ou expulsos pelos europeus, com o objetivo de apagar da memória da ilha os vestígios de habitantes autóctones.

E por fim, a última hipótese diz respeito à descendência, com base em dados históricos e lingüísticos, nos quais o léxico da língua dos angolares, a lunga n'golá revela um crioulo com $65 \%$ de palavras de origem portuguesa e $14 \%$ de termos de origem bantu, originário da grande ocor- 
rência de fugas de escravos ao mato, por ser a ilha um ponto de parada dos navios negreiros que rumavam aos portos importadores.

Como tradição oral, essas hipóteses têm sido transmitidas a cada geração e constituem a base do chamado 'imaginário angolar'. Mata (2004) afirma que, apesar das hipóteses apresentadas por Fernando de Macedo e das incertezas quanto às origens angolares, sabe-se que os angolares mantiveram uma sociedade paralela à colonial com a qual contatavam apenas por razões econômicas, como empreitadas para roçar o mato e o fornecimento de pescado a determinadas zonas da ilha. O crescimento da cultura do café e do açúcar no século XIX, por conseguinte, torna-se o principal motivo para as campanhas contra os angolares e sua invulnerabilidade, com o objetivo de evacuarem as terras férteis do sul da ilha.

Assim, na história do povo angolar distinguem-se, de acordo com Macedo (1996), três períodos diversos: o primeiro transcorre durante 153 anos de guerrilha e pressão sobre o nordeste da ilha, iniciado no suposto naufrágio de 1540 e vai até a primeira expedição punitiva chefiada pelo 'Capitão Mor dos Matos', Mateus Pires, em 1693; o segundo período, com duração de 185 anos, época na qual o reino angolar viveu em paz, inicia-se quando ocorre o reconhecimento da autoridade do 'Capitão dos angolares' e termina com a ocupação de Santa Cruz em 1878; o último decorre dos cem anos seguintes, quando os angolares, espoliados de suas terras, fixam-se no litoral e dedicam-se às atividades de pesca.

É importante destacar que, por possuírem características próprias, seja no âmbito social, econômico ou cultural, os angolares formam um povo peculiar na constituição de São Tomé e Príncipe e, consequentemente, na permanência de determinadas manifestações culturais. Isso fortifica os valores identitários, sobretudo através de relatos de memória, da valorização de crenças e da reatualização de mitos, e embasa a literatura dramática escrita por Fernando de Macedo.

\section{O REI DO OBÓ: O TEXTO TEATRAL E A LEMBRANÇA DO PRIMEIRO REI DOS ANGOLARES}

O texto O Rei do Obó ${ }^{2}$, peça escrita por Fernando de Macedo no ano de 1999, mostra a saga do Rei Amador, figura que marca o imaginário da população de São Tomé e Príncipe. O Rei Amador tem seu nome vinculado às variadas versões históricas de povoamento da ilha, assim como as versões da origem dos angolares. Suas características de liderança e seu apego à terra têm estreita ligação com os heróis da "Guerra-do-Mato", parte da tradição são-tomense. Tornou-se figura importante da tradição local por ser célebre guerreiro que, ao comandar grupos de angolares e outros revoltados, avançou sobre a capital de São Tomé e teria sido enforcado em 1596.

A tradição oral, ainda hoje corrente, considera o Rei Amador originário da Praia Grande (a sul de Anguéné), perto de Ribeira Peixe, antigo centro de resistên- 
cia angolar, o qual, ao dinamizar o seu povo e libertar cativos, teria avançado vitoriosamente em luta montada até ser mortalmente atingido. $\mathrm{O}$ mito de Amador alargou-se a ponto de muitos afirmarem ouvir o trote do seu cavalo a rondar as praias durante a noite. Para além do sentido mítico, Amador tornou-se um símbolo nacional (MACEDO, 2000, p.135).

Celebra-se em São Tomé e Príncipe, no dia 4 de Janeiro, um feriado nacional dedicado ao Rei Amador. Sua figura também aparece na cédula de 'dobra', a moeda são-tomense. Diz-se que Amador foi pioneiro no império português por ser o primeiro o organizar uma revolta de escravos oriundos do tráfico negreiro, e foi um dos primeiros a lutar pela causa da terra, pelo solo sagrado que acolheu seus antepassados e sobre o qual acreditava ser capaz de construir uma nação igualitária e livre do domínio colonial.

Conforme Crippa (1975), a cultura não se define a partir do homem: o homem cria a cultura através da ação fundadora das possibilidades culturais. Seus projetos, aspirações, valores, desejos, necessidades e ideais formam, por si só, o campo de manifestação das realidades humanas, e o homem planeja e edifica o seu mundo de acordo com suas memórias, seus ideais, necessidades e conveniências. Este, portanto, se revela sujeito criador nas mais diferentes esferas e situa-se num mundo significativo, seja no âmbito social e político ou na expressão de sua arte, e exprime sua cultura através de um novo sentido de realidade e uma nova possibilidade de ser. A narrativa do Rei Amador, num primeiro momento não reconhecida oficialmente, estimulou essa edificação de mundo num percurso de ideal nacionalista, e é somente após a independência de São Tomé e Príncipe, em 1975, que o mito é oficialmente reconhecido e, posteriormente, aparece representado no texto teatral de Fernando de Macedo.

O drama $O$ rei do obó é dividido em cinco partes, sem designação de atos, cenas ou quadros, e apenas há a organização dos fatos de acordo com o andamento da trama. Do que poderia restar de uma suposta divisão baseada no modelo clássico de construção do drama, o que explicitaria o desenvolvimento da ação dramática, percebe-se, no texto de Fernando de Macedo, menos ênfase ao equilíbrio da estrutura em si, mas às oscilações de tensão que, inevitavelmente, atrelam-se aos acontecimentos sobrenaturais. Portanto, a divisão do texto em cinco partes desiguais em termos de tamanho e fluxo de ações, dá ao autor certa permissão para extravasar os acontecimentos na medida de sua necessidade, com tantas situações e personagens quanto o requerido cenicamente para a discussão do mito.

As personagens movimentam-se em três planos: as que transitam entre o tempo presente de desenvolvimento do drama e o tempo mítico; as que vivem apenas no tempo mítico e aquela que não se atreve a entrar no terreno sagrado - a jovem esposa do ancião que prefere voltar para casa e continuar com suas lidas cotidianas. Na primeira parte, quando o autor apresenta a situação, tem-se a chegada de Luísa Bôbô à casa do nonage- 
nário Mantana. Luísa é definida como uma mulher de virtude ${ }^{3}$, de meia idade, afamada pelos seus 'saberes deste mundo e do além' e é recebida por Hirondina, a jovem esposa dele que, surpreendida, conduz a visitante até o marido. Desde o início pressente-se que há uma missão a ser cumprida, relacionada a algo sobrenatural. As personagens citam a participação no djambi, a cerimônia realizada para afastar as almas que andam pelo 'obó. Luísa e Mantana sentem-se atraídos ao 'sagrado terreiro' e, através das visões noturnas dele, revela-se o chamado de Amada, a companheira do Rei Amador. Segue-se a descrição da visão:

MANTANA: (...)Todo o obó estava com estranha luz... vi Amada com o regaço cheio de goiabas douradas, rodeadas de enormes cobras. Ela com o medo deixou de gritar, mas os seus olhos pediam ajuda. Ainda hoje aquela aflição me segue por toda parte...

LUÍSA BÔBÔ (mostrando crescente interesse): E depois? Viste mais alguma coisa?

MANTANA: Nem mesmo a chegada de Amador lhe acalmou a comoção. Mas ele, com a sua catana, degolou mais de cem serpentes, abraçando a jovem finalmente (MACEDO, 2000, p. 21).

A presença do caráter sobrenatural é percebida desde o início do drama e situa o leitor/espectador nos movimentos de transposições espaciais e temporais: da casa de Hirondina e Mantana para o reino de Amador e do tempo presente para o retorno a séculos anteriores. Nas transposições da memória, não acontece apenas a rememoração dos fatos, mas, através do conflito estabelecido, clarifica-se a necessidade de resolução de um problema do passado na retomada do tempo presente.

Para Hamburger (1986), a abordagem da ficção dramática pressupõe a análise da fenomenologia do palco. Assim, a questão da mimese deve ser considerada sob o ponto de vista da representação da realidade e da problemática do tempo, numa transposição do modo da imaginação para o modo da percepção. O tempo de narração do drama se transforma em tempo de encenação e se sujeita às condições de uma realidade tempo-espacial ao abrigar a diferença entre os tempos fictício e real. Dessa forma, a retomada da memória é propícia ao tempo da encenação, pois permite a recriação do passado e de situações que fundamentam a trama. Através de "uma nova apreensão que, ao criar sentidos, fugazes eles também, permite jogos ativos com o(s) tempo(s) e no(s) tempo(s), isto é, uma inter-ação com ele(s)" (GAGNEBIN, 2006, p.173).

Há, nessa primeira cena, a presença oculta dos 'flamengos', que fazem oposição à realização do objetivo de Mantana, citados como "estranhas almas penantes com ventres impados de ambição e mordazes dentes descarnados" (MACEDO, 2000, p. 22). Essas almas têm como função aterrorizá-los para que não cumpram o que têm a fazer. Conforme a tradição 
angolar, a expressão 'flamengo' é utilizada de forma depreciativa para significar 'homem branco de mau caráter'. Existe, portanto, um embate entre o sentido sagrado que impulsiona a empreitada e a presença constante do dominador europeu que tenta apagar a força sagrada autóctone. Ainda assim, o sobrenatural sobrepõe-se na relevância do 'chamamento' que, como enfatiza a personagem de Luísa Bôbô, dá forças ao velho e fraco Mantana. Definido o problema e criada a expectativa em relação ao chamamento de Amada, encerra-se a primeira das cinco partes do drama, com a entrada das três personagens mato adentro num primeiro momento de maior tensão dramática.

Com relação ao estilo de tensão dramática, Staiger (1993) afirma que a expressão "problema", tem acepção real de "proposto" (das Vorgeworfene) que o autor terá que atingir em seu percurso. Inicia-se num ponto de partida e se desenvolve em linha reta até seu desfecho, numa interdependência das partes textuais que gera a tensão. No estilo problemático, o objetivo da história está no fim: cada parte deve ser examinada exclusivamente em função do todo que, no final, se estabelece, ou seja, se monta através dos fatos recriados.

Na segunda parte, a cena inicia com a chegada dos três na clareira onde se pratica o djambi. Há visível alteração no físico das personagens: o velho fica mais ágil e a jovem move-se com dificuldade, quase paralisada de medo. O ruído de passos faz com que ela desista de adentrar no campo sagrado e retira-se sem que os outros percebam, pois estão completamente absorvidos pelo que veem:

Um vulto vestido de negro vai-se tornando cada vez mais nítido. Parece uma mulher de meia idade trazendo nas mãos um bordão semi-curto envolto num pano vermelho.

MULHER DE NEGRO: Se têm medo podem ir-se embora. Mas se quiserem entrar neste recinto sagrado, têm de esfregar as mãos, a cara e os pés com folhas de mangungu (MACEDO 2000, p. 25).

Há, a partir das exigências da Mulher de Negro, a preparação para o ritual, uma maneira de transpor as fronteiras para o tempo do mito. $\mathrm{O}$ rito é a prática que reatualiza o mito a partir do retorno a ele, que retoma e recria determinado universo. Conforme Eliade (1992), os modelos míticos partem sempre de uma era primordial, in illo tempore, um tempo sagrado, quando determinado ritual foi celebrado pela primeira vez por um deus, um ancestral ou um herói. Esses modelos partem de um novo ritual para reviver essa era primordial no tempo presente, no intuito de sacralizar o próprio tempo. A regeneração periódica do tempo pressupõe, através do ato cosmogônico, a concepção de final e início de um período temporal, assim como a regeneração periódica da própria vida. Existe, então, uma tentativa de repetição do instante mítico, da passagem do caos para o cosmo, com o objetivo de restaurar a pureza daquele instante. 
O ritual da Mulher de Negro, espírito que, posteriormente, revela ser a mãe do Rei Amador, prepara o encontro das personagens com a figura mítica. É necessário que estejam purificados e livres de suas vestes mundanas: colocam vestes brancas que se encontram sob uma sebe e esfregam-se com folhas de mangungu, planta que, pela tradição, tem a virtude de denunciar um criminoso quando colocada sobre suas mãos.

MULHER DE NEGRO: Vejo que tendes fé e boa intenção. Agora, já podem entrar neste recinto sagrado.

Luísa Bôbô e Mantana avançam um pouco. Luísa está muito interessada e curiosa.

MANTANA (depois de entrar, dirige-se a meia voz para Luísa): Sinto-me muito mais novo e sem dores. Que estranho! (MACEDO, 2000, p. 26).

A entrada na clareira sagrada prepara um segundo e mais forte momento de tensão no decorrer da ação. É o encontro das duas personagens com Amador e sua companheira, antes de autodeclarar-se Rei e nos momentos anteriores à decisão de tomar o comando da luta dos escravos. Pressupõe-se, nesse fato, a proposta de representação do surgimento do mito, que depende apenas da aprovação paterna para iniciar a trajetória que o imortalizou. Após o conselho da Mulher de Negro aos visitantes, que adverte: "Se a ambos foi permitido entrar aqui, nem foi por acaso, nem será em vão. Agora é vosso dever estar atentos e descerrar os olhos da alma" (MACEDO, 2000, p. 27). Há a visão do resto da clareira onde está Amador em aparente indecisão, junto com Amada, que o acarinha e encoraja, e cercado por guerreiros nervosos com armas em punho. Ao saber da morte do pai, recebe das mãos de sua mãe o bastão sob o pano vermelho, que desvela o sentido nacionalista do mito enfatizado pelo autor: "Agora é teu, pois as febres já tiraram a vida daquele que o segurava por amor ao nosso povo" (Idem, Ibidem, p.28). É o primeiro impulso que faz com que ele assuma o dever da luta e empreenda a grande revolta dos escravos na ilha.

Mesmo tomado pelo ímpeto da luta, a ação não se dá antes que ele reúna forças e sacralize seus atos junto à mística Budo-Bachana, rocha existente no sul da ilha de São Tomé. Conforme a tradição oral, sempre que tocada por um inimigo do povo angolar, Budo-Bachana emite a esse poderes maléficos. A força mágica da rocha representa a união entre a força telúrica da natureza e a força anímica do povo, associada ao sentimento de vingança das opressões sofridas pelos antepassados. Aumenta, assim, para a figura de Amador, a intensidade da missão libertadora, o que o alça, em termos históricos, a uma posição icônica na estruturação social da ilha e, sobretudo, na memória da formação no povo angolar:

AMADOR: (Compondo o pano vermelho sobre as suas costas, ternamente ajudado por Amada): Não é leve esta capa para quem está rodeado de inimigos!

AMADA: (Coloca-lhe um aro de folhas na cabeça): Li- 
berta primeiro cativos e escravos! Eles te ajudarão na luta juntando-se aos nossos.

MULHER DE NEGRO: Serás o libertador de nossos povos!

CORO (de todos os outros presentes): Liberdade! Viva Amador!

\section{Amador levanta-se erguendo o bastão.}

CORO: Amador, liberta nosso chão! (Idem, Ibidem, p. 27).

Para Adolpho Crippa (1975), a história dos diferentes povos e culturas principia sempre com um capítulo que se dedica à época primordial ao tratar da gênese dos acontecimentos passados e futuros. Nesses fatos, encontram-se deuses, semideuses, heróis e homens especiais que participam de acontecimentos transcendentais, decisivos, singulares e únicos. E assim, "como conseqüência da iniciativa e da ação divinas surgem os grandes modelos que marcam ou definem o estilo de um povo ou de uma civilização” (CRIPPA, 1975, p. 12). A 'divinização' do Rei Amador, perpassa, por conseguinte, uma atitude decisiva tomada como transcendental. No momento em que ele arca com a responsabilidade da luta pelo povo, torna-se figura chave de identificação daquele próprio povo e sua terra.

$\mathrm{Na}$ terceira parte do drama, há alteração no espaço cênico e o leitor/espectador é transportado a um terreno de engenho repleto de escravos. Os homens cortam cana e as mulheres transportam para uma roda movida por dois escravos onde a cana é espremida. Um capataz bate impacientemente com uma vara no chão e marca a cadência do trabalho. As personagens Luísa Bôbô e o velho Mantana observam de um canto do palco, semi-ocultos. Eles estão na terra do engenho, mas agem como espectadores e se inserem na cena como parte de outra realidade. Nesse espaço, eles são seres sobrenaturais. Percebe-se clima de tensão e rebeldia na relação dos escravos com o capataz. A mulher recita versos em intertexto do poema Geme teu grito engenho, de Anguéné, obra do próprio autor:

Pela boca dos escravos; geme teu grito engenho; a cana só dá seu sangue; entre chicote e agravos.

Corta e recorta sofrido; suado corpo carrega; da terra 'húmido' néctar; pr'a ser esmagado e sorvido (MACEDO, 1989, p.39).

A chegada de um corsário ferido interrompe o trabalho e faz com que aumente a tensão entre os trabalhadores. Nesse momento do drama, prepara-se a entrada do Rei, já como salvador do povo. O corsário afirma ser fugitivo de um ataque de guerrilheiros angolares e o simples fato de evocar o nome de Amador e afirmar sua aproximação do engenho faz com que os escravos sintam-se autoconfiantes e avancem sobre o capataz. Esse, acuado, desfere tiros à toa, foge para o obó e abre espaço para a entrada triunfante de Amador e seus seguidores, na indicação cênica do autor: "com grande 
alegria os escravos abraçam os guerrilheiros e reverenciam a figura mítica do Rei" (MACEDO, 2000, p. 33). A discussão entre o corsário e Amador dá ênfase ao caráter heróico da personagem, pois, mesmo que o primeiro alegue serem ambos aliados no combate aos colonos, o segundo deixa definidas as suas diferenças: o Corsário é um branco, anteriormente classificado pelo capataz de 'flamengo', dos que saltam dos navios para saquear os engenhos. Amador, ao contrário, afirma que sua missão não é roubar, mas libertar aqueles que estão cativos. E enfatiza: "tu não entendes o que é para nós o sagrado chão. Nós lutamos pela liberdade, não pelo ouro." (idem, p. 34). A ação pela terra sagrada torna-se vital na busca pela identidade do povo que ele representa. O sentido de nacionalismo ou os fundamentos de uma futura nação germinam através da memória de Amador, na luta pela igualdade e contra a exploração dos seus. Ao drama de Macedo associa-se a afirmação de Smith: a idéia de nação encontra-se no centro de um dos mitos mais populares do mundo moderno, o próprio mito do nacionalismo, que carrega em si a idéia de que "as nações existem desde tempos imemoriais e que os nacionalistas devem despertá-las do seu longo sono, para que ocupem seu lugar num mundo de nações" (SMITH, 1997, p.35).

Tem-se como princípio de promessa o próprio conflito de salvação nacionalista, que é aumentado pela presença de tradições nas memórias, símbolos, mitos e valores de épocas anteriores à própria comunidade. $\mathrm{O}$ nacionalismo liga-se diretamente à terra e às profundas raízes de uma nação (SMITH, 1997). Seus aspectos práticos juntam-se aos simbólicos na demarcação de uma terra natal, definida pela história e pelo local onde viveram seus antepassados. A localização da nação, por conseguinte, depende, a nível subjetivo, da interpretação de sua história étnica e das memórias da comunidade.

Após libertos, os escravos acompanham Amador ao acampamento. A terceira parte do drama termina num esvaziamento da tensão que antes predominava e dá lugar a um clima de esperança e tranqüilidade. Ex-escravos e ex-escravas retiram-se para namorar em liberdade no canavial e são observados ao longe por Mantana e Luísa, que recita o último verso do poema de Anguéné: "Ai doçuras verdejantes, canas dançantes ao vento, em quantas de tuas folhas houve suspiros de amantes!" (MACEDO, 2000, p. 36). A natureza é exaltada como aquela que proporciona o solo fértil para a procriação e continuidade no surgimento de outras gerações. $\mathrm{O}$ velho Mantana, símbolo de sabedoria e tradição, docemente concorda.

A quarta e penúltima parte do drama apresenta uma nova situação e outro espaço cênico. Vê-se uma Igreja rural e a residência do Padre com um alpendre meio encoberto, segundo indicação do autor. Mantana e Luísa aproximam-se do local e encontram um casal, ela alforriada por ter tido um filho do patrão e ele fugitivo, e logo entendem que pedem refúgio na casa paroquial. O Padre cede a contragosto, e evidencia o medo da reação desmedida dos fazendeiros. A chegada do dono do engenho e de seu encarregado é o mote para que revelem a situação dos engenhos abandona- 
dos pela fuga dos escravos: "Ora veja, Frei Afonso, dos cerca de trinta engenhos já só restam oito ou nove, incluindo o meu. Se cada um tinha para cima de oitenta escravos nos canaviais e na fabricação, veja quantos fujões já nos escaparam!” (MACEDO, 2000, p. 44). Segue-se a discussão sobre o conflito deflagrado por Amador e pelos angolares, o que é um prenúncio de um novo ataque. $\mathrm{O}$ autor utiliza-se do dialogo para situar historicamente a trama, com as personagens Frei Afonso e Basílio, dono do engenho, ambos portugueses, a comentar fatos históricos da ilha como: a Revolta dos Lobatos, em 1517, o ataque de corsários franceses, em 1567, a revolta dos angolares em 1974, e, para Portugal, as conseqüências da Batalha de Alcácer-Quibir, em 1578, que originou o mito do sebastianismo. ${ }^{5} \mathrm{~A}$ chegada de um jovem mensageiro coloca a todos em alerta ao anunciar que a fazenda está cercada e que os capatazes fogem para a Povoação com as mulheres e os filhos. Arma-se grande confusão e todos correm para salvar seus próprios filhos. Num segundo momento, o escravo fugitivo, chamado N'Gola sai de seu esconderijo e dialoga com Mantana e Luísa sobre a presença das crianças durante o conflito:

N'GOLA: Dona, as crianças são sagradas. Nós arriscamos a vida por elas, e muitos morrem na luta. Apesar da tristeza, é bom que os meninos vejam para que não esqueçam amanhã o preço da liberdade.

LUÍSA BÔBÔ: Dizes bem. Por falta de nascença não acabará a nação (MACEDO, 2000, p.51).

Prepara-se, assim, a conscientização de um novo ciclo, da criação de uma nova realidade com o nascimento de outras vidas. A idéia de ciclo, que embasa o pensamento mítico e se afirma no encaminhamento final do drama, evidencia-se com a gravidez da companheira de Amador. É a partir desse fato que a idéia de perpetuação de valores se estabelece, assim como a clarificação da necessidade e do dever de se manterem vivas a memória e a tradição local. Em Mito e realidade, Eliade (2007) traça um paralelo entre os mitos de origem e o mito cosmogônico, e afirma que as origens sistematicamente esboçam esse sentido de cosmogonia. Assim, para contar a genealogia de uma família real, por exemplo, ou uma história da comunidade, ou a história de origem de qualquer outro fato, esses mitos de origem prolongam e completam o mito cosmogônico.

$\mathrm{Na}$ última parte do drama, determina-se a permanência dos fatos históricos e fixa-se Amador como um dos principais mitos de origem do povo da ilha de São Tomé. O fato principal, que antecipa o ataque final, é a morte de Conde Silvestre, o Capitão mais estimado pelo Rei, durante um ataque surpresa dos colonos. $\mathrm{O}$ aparecimento do colono fugitivo João de Pina $^{7}$ é o início de uma sucessão de entradas e saídas de personagens que se estende até o final do drama, caracteriza o clímax final e o desfecho da trama. Todos estão feridos e trazem a sua visão da luta. Há a passagem do capitão Duarte Amarocco, com as mãos decepadas e as roupas ensangüentadas: é uma das figuras históricas, guerrilheiro de Amador, que sofreu vingança por ter matado seu senhor: 
DUARTE AMAROCCO (em voz sofrida): Conquistamos tudo menos o forte. Eu já não agüento mais. Quero ver as minhas filhas antes de morrer. Dei a vida por nosso Reino! (prosseguindo caminho) $\mathrm{O}$ fogo das bombardas confundiu as nossas hostes. A desordem instalou-se. Dizem que alguns Capitães foram atingidos. Não sei mais nada. Sei que cumpri o meu dever. Os nossos antepassados são testemunhas disso... (Como ia se afastando, embora lentamente, as últimas palavras já não se entendiam com clareza.)

(MACEDO, 2000, p. 60).

Entram em cena a Mulher de Negro, mãe de Amador e Amada, grávida. A mãe convida Luísa a realizar a oração dos mortos, numa evocação ao espírito dos Capitães que não resistiram à batalha. Juntas, e num gestual proposto pelo autor de levantar "teatralmente os braços ao céu", tornam-se o axis $^{8}$ sagrado, e fazem a ligação entre a terra e o mundo dos espíritos. Em coro, chamam os espíritos do obó, os heróicos antepassados e os Capitães, como afirmam: "mortos na luta por nosso chão!" (MACEDO, 2000, p. 60). Rogam que se abram as portas de Budo-Bachana, a rocha sagrada, antes da hora da vingança. Numa aparição sobrenatural, surgem às suas frentes as figuras dos Capitães que compõem história da Revolta de Amador: Conde Silvestre, Lázaro, Preto, Anna e Prata. ${ }^{9}$ Todos clamam em coro, no momento de maior tensão e lirismo na evolução da ação:

\author{
LÁZARO: Ficarão nossos olhos \\ em brilho gravados \\ no extenso manto \\ da montanha sagrada \\ sobre chão ensanguentado.
}

TODOS OS CAPITÃES: Terra de sangue dos que por ela sofreram tortura e morte!

\author{
LÁZARO: Sagrado Budo-Bachana \\ esconjura os opressores \\ pois a vitória tarda!
}
TODOS OS CAPITÃES: Transforma o sofrimento de livres e escravos em vigorosa seiva!
LÁZARO: Acorda a memória do sono do tempo e apressa a hora do pão e da glória!


TODOS OS CAPITÃES: Acorda a memória

do sono do tempo

e apressa a hora

do pão e da glória!

(MACEDO, 2000, p.60-61).

O vento que sopra em cena e move folhas e arbustos é o prenúncio da derradeira aparição do Rei. Os espíritos saem de cena e o som cadenciado de tambores se torna cada vez mais audível. Entra o cadáver de Amador, numa padiola, transportado por dois guerreiros no clímax do drama. Todos em silêncio, com postura de reverência seguem Amada, que beija o morto. A seguir, em atitude digna, ela retira o pano vermelho que o envolve, coloca sobre si e toma nas mãos o bastão. Evoca novamente os espíritos dos Capitães, que reaparecem, e, com coragem, afirma: "Vamos! Uma batalha não é o fim da nossa luta!” (MACEDO, 2000, p. 63). É erguida por vivos e mortos e carregada ao som de tambores que se acelera em ritmo de guerra ${ }^{10}$. Luísa, Mantana e o corpo de Amador ficam em cena enquanto o som dos tambores baixa e dá lugar a uma melodia tocada em pitu dóxi $i^{11}$. O autor propõe uma transição de planos através da alteração de iluminação e sonoplastia: a luz deve desaparecer sobre Amador até que não seja mais possível vê-lo. A seguir, ilumina-se um novo dia sobre o ancião e a mulher de virtudes. Ao perceberem o desaparecimento de Amador, entendem o sentido de terem sido chamados àquela missão: "Que a sombra do nevoeiro não caia sobre a nossa memória!" (MACEDO, 2000, p. 63), diz Mantana. E imediatamente percebem que devem manter vivos os mitos da terra e sua história.

A ação dramática altera seu curso com a passagem de um grupo de crianças que atravessa a cena e deixa cair um livro com páginas em branco. A seguir, ao fundo, aparece a montanha de pedras Budo-Bachana, que está iluminada com pontos brilhantes. Dela saem rumores, música e vozes: "Luta e glória não se esquece! Mesmo de noite grita e aparece!" (MACEDO, 2000, p. 64). As crianças recolhem o livro, olham para a montanha e, espantadas, escutam: "Cantai meninos cantai! Cai o ontem no presente como futuro em semente! Cantai meninos cantai!" (MACEDO, 2000, p. 64). A montanha sagrada aponta para um novo tempo, que não se exime do passado para recriar o presente. $\mathrm{E}$ as crianças, símbolo máximo de renovação e futuro, levam no livro em branco uma nova história a ser escrita e, protegidos por Budo-Bachana, reiniciam ciclos e dançam em círculos: de mãos dadas com a sabedoria do velho Mantana e a experiência de Luísa Bôbô, mulher de virtudes da terra.

TODOS: Cantemos todos agora alegrando o coração a seiva que vem da terra é a força da nação.

(FIM)

(MACEDO, 2000, p.64). 


\section{CONSIDERAÇÕES FINAIS}

No drama $O$ Rei do Obó, a relação do herói mítico com a terra e suas memórias, a luta pelo fim da exploração externa e a afirmação da identidade através dos valores autóctones remetem aos conflitos do período pós-colonial: o apagamento de tradições, a sobreposição de culturas, o enquadramento num sistema econômico-político-social que reduz a riqueza dos valores primordiais ou os trata como adornos de uma realidade globalizada. Nesse sentido, a dramatização do problema por Fernando de Macedo que, já no século XX, retorna cinco séculos para encontrar princípios da questão, confere ao teatro de São Tomé e Príncipe e suas manifestações cênicas o papel de exprimir crenças e costumes, que têm nos mitos e memórias locais uma valiosa fonte para manifestações artísticas genuínas e atuais. Dessa forma, essas manifestações de cunho fundamental contribuem culturalmente para a formação da própria identidade nacional:

Embora a produção teatral em São Tomé e Príncipe tenha, por muito tempo, se contentado com as glórias de formas artísticas institucionalizadas, houve, nos últimos anos, uma tentativa de reapropriação dos mitos folclóricos e antigas tradições teatrais em peças cujas temáticas são reatualizadas (MITRAS, 2004, p. 402). ${ }^{12}$

Conforme Smith (1999), pode-se afirmar que a narração da nação e o conceito de povo hoje é parte de um caráter híbrido e eclético. Portanto, ainda que existam diferentes visões e antagonismos a respeito de determinados tratamentos dos fatos - o que é perfeitamente aceitável ao se tratar de manifestações artísticas - a identidade nacional torna-se, assim, híbrida e ambivalente: utiliza um tempo duplo, com uma cisão entre a narrativa com autoridade histórica e pedagógica do povo e a narrativa de significação repetitiva e performativa da vida cotidiana. Forma-se, por conseguinte, a partir de vestígios e rastos de memória, na recolha de lendas contadas pelos mais variados tipos de indivíduos e grupos sociais e na seleção dos fatos constituintes da narrativa histórica. Para tanto, considera-se o cruzamento entre essa narrativa e a narrativa ficcional, que se reconfigura, segundo Ricoeur (1985), numa nova apreensão de sentidos, do tempo e da vida.

\section{REFERÊNCIAS BIBLIOGRÁFICAS}

CRIPPA, Adolpho. Mito e cultura. São Paulo: Convívio, 1975.

ELIADE, Mircea. Mito do eterno retorno. São Paulo: Mercuryo, 1992. Mito e realidade. São Paulo: Perspectiva, 2007.

GAGNEBIN, Jeanne Marie. Lembrar, escrever, esquecer. São Paulo: Ed.34, 2006.

HAMBURGER, Kate. A lógica da criação literária. São Paulo: Perspectiva, 1986. (2a ed.). 
MACEDO, Fernando de. Anguéné: gesta africana do povo angolar de São Tomé e Príncipe. Lisboa: Sá da Costa, 1989.

. O povo angolar de S. Tomé e Príncipe. S.

Tomé: Instituto Rei Andreza para a Cooperação e Desenvolvimento, 1996. ( $3^{\text {a }}$ ed.).

. O rei do obó. In Teatro do imaginário ango-

lar. Coimbra: Cena Lusófona, 2000.

MATA, Inocência. A suave pátria: reflexões político-culturais sobre a sociedade são-tomense. Lisboa: Colibri, 2004.

MITRA, Luís. The islands (Cape Verde and São Tomé and Príncipe) in A history of theatre in Africa. Cambridge: Cambridge-USA, 2004.

NDAW, Alassane. La pensée africaine: recherches sur les fondements de la pensée négro-africaine. Dakar: Les Nouvelles Éditions Africaines, 1983.

NEGREIROS, Almada. Historia ethnographica da ilha de S. Thomé. S. Thomé: s/n, 1893.

PEREIRA, Renato Pignatari. A construção do nacionalismo em São Tomé e Príncipe. Disponível em: <http://www.klespsidra.net/klepsidra13/ saotome.doc>. Acesso em 04 jan. 2009.

RICOEUR, Paul. Temps et récit, III, Le temps raconté. Paris: Seuil, 1985.

SMITH. Anthony D. A identidade nacional. Lisboa: Gradiva, 1997.

STAIGER, Emil. Conceitos fundamentais da poética. Rio de Janeiro: Tempo Brasileiro, 1993. (2aed.)

TENREIRO, Francisco. A ilha de São Tomé. Lisboa: Memórias da Junta de Investigações do Ultramar, 1961.

VALE, Fernando. Contos tradicionais dos países lusófonos. Lisboa: Instituto Piaget, 2001. (2 ed.)

Recebido para publicação em 15/04/2013

Aprovado em 22/07/2013

\section{NOTAS}

1 Sete Pedras - rochas altas e aguçadas que rompem o mar em frente ao extremo sul da ilha de São Tomé. Segundo a tradição portuguesa, sem confirmação científica, teria aí naufragado um barco transportando cativos. Estes, logrando alcançar a costa, teriam dado origem ao Povo Angolar. Admite-se, todavia, que os Angolares tenham alcançado a ilha (onde ainda hoje vêm parar troncos provenientes da costa africana), por seus próprios meios, provenientes do Continente. As Sete Pedras têm ainda hoje um significado mítico para os Angolares, que as consideram símbolo de resistência a culturas estranhas (MACEDO, 2000). 
2 Obó: floresta ou mato fechado.

3 Mulher de virtude ou santificada: possui o dom de receber e interpretar mensagens do além. (MACEDO, 2000).

4 Anguéné - Santa Cruz dos Angolares em idioma angolar. Nas cercanias dessa cidade, em Maculu, teria sido a sede do reino Angolar. Em sentido amplo, essa expressão significa 'terra angolar'.

5 A Revolta de Amador, época da trama, foi em 1595.

6 N’gola: o mesmo que Angola. Provável referência à origem dos angolares.

7 Conforme Rosário Pinto, seria o dono da égua apossada por Amador no seu avanço para a capital (MACEDO, 2000).

8 Eixo.

9 Na História da Ilha de S. Tomé, publicada em 1734, o Deão Manuel do Rosário Pinto descreve em pormenores o levantamento do Amador. Refere os vários Capitães que acompanhavam aquele Rei: Conde Silvestre, 'cabo do inimigo', morto em combate; Lázaro, 'o maior Capitão'; Adão Praia Prata que, como o anterior, sofreu pena de enforcamento; os Capitães Preto e Anna, que tiveram a mesma sorte; e Duarte Amarroco, a quem deceparam as mãos antes de lhe ser aplicada a pena capital (MACEDO, 2000, p. 136).

10 Em Conceitos Fundamentais da Poética, o autor Emil Staiger (1993) trabalha com duas expressões relativas ao estilo de tensão na dramaturgia: o pathos e o problema. A linguagem do pathos pode ser confundida com a linguagem lírica, pois tanto o êxtase lírico quanto o arrebatamento patético podem provocar reações espontâneas em termos de palavras ou balbucios. O clímax do pathos num drama, através do patético, quebra freqüentemente as concordâncias gramaticais e conduz o discurso numa elevação de um ponto a outro. Na definição do termo, pathos pode ser traduzido por vivência, desgraça, sofrimento, paixão. Segundo Aristóteles, a alma humana é dividida em páthe, dynámeis e héxeis, sendo que a patética compreende as "paixões", no sentido geral do termo. O homem, portanto, é movido por paixões, e Aristóteles retoma, em sua Arte Retórica, a qualidade do discurso patético, ou seja, do discurso que atua sobre as paixões e domina o homem. Na definição moderna, porém, a expressão toma um sentido diferente do sentido grego e passa-se a considerar como termo pathos não tanto a paixão em si, mas o tom patético que provoca paixões. Nesse sentido, é relevante diferenciar a fala patética da linguagem lírica, já que os gregos consideram pato-lógico tudo que comove ou perturba o espírito. A ação do pathos pressupõe um tipo de resistência que rompe com o ímpeto, seja através de um choque brusco ou da apatia. A força da fala se concentra em palavras soltas e não se dilui no tom onírico da obra lírica. A fala patética pressupõe algo fora de si e, diferentemente da linguagem épica, não quer reconhecer este algo, procura suprimi-lo deixando o orador conquistar o ouvinte que, por sua vez, sofre o impacto desse discurso.

11 Flauta local.

12 Tradução da autora. 